\title{
PENGARUH KUALITAS PELAYANAN DAN CITRA MEREK TERHADAP KEPUASAN WISATAWAN NUSANTARA MENGGUNAKAN TRANSPORTASI ONLINE GRAB DI KUTA, BALI
}

\author{
Maria Laru Sendy Ludju', I Made Kusuma Negara ${ }^{2}$, Ni Putu Eka Mahadewi ${ }^{3}$ \\ Email: marialarusendy@gmail.com ${ }^{1}$, kusuma.negara@unud.ac.id ${ }^{2}$, eka.mahadewi23@gmail.com³ \\ ${ }^{1,2,3}$ Program Sarjana Industri Perjalanan Wisata, Fakultas Pariwisata, Universitas Udayana
}

\begin{abstract}
This study aimed to explain the effect of service quality and brand image on the satisfaction of domestic tourists who used Grab online transportation in Kuta, Bali. The research method used in this research was quantitative and qualitative research methods (mix methods). Questionnaires were distributed to 150 domestic tourists with a sample determination method using purposive sampling. The method of data analysis used multiple linear regression analysis with SPSS 18.0 program. The results of this study stated that partially the quality of service had a positive and significant effect on the satisfaction of domestic tourists with the dominant dimension being the tangible dimension and brand I mage giving a positive and significant effect on the satisfaction of domestic tourists with the dominating dimension being the support of the brand association. Simultaneously, the quality of service and brand image had a positive and significant influence on the satisfaction of domestic tourists. The R Square value of 0.672 meant that $67,2 \%$ of tourist satisfaction could be explained by the variable service quality and brand image, while the remaining $32,8 \%$ was influenced by other variables not examined in this study.
\end{abstract}

\begin{abstract}
Abstrak: Penelitian ini bertujuan untuk menjelaskan pengaruh dari kualitas pelayanan dan citra merek terhadap kepuasan wisatawan nusantara yang menggunakan transportasi online Grab di Kuta, Bali. Metode penelitian yang digunakan dalam penelitian ini yaitu metode penelitian kuantitatif dan kualitatif (mix methods). Kuesioner disebarkan kepada 150 wisatawan nusantara dengan metode penentuan sampel menggunakan purposive sampling. Metode analisis data menggunakan analisis regresi linear berganda dengan program SPSS 18.0. Hasil dari penelitian ini menyatakan secara parsial kualitas pelayanan memberikan pengaruh positif dan signifikan terhadap kepuasan wisatawan nusantara dengan dimensi yang mendominasi adalah dimensi berwujud dan citra merek memberikan pengaruh positif dan signifikan terhadap kepuasan wisatawan nusantara dengan dimensi yang mendominasi adalah dukungan asosiasi merek. Secara simultan kualitas pelayanan dan citra merek memberikan pengaruh positif dan signifikan terhadap kepuasan wisatawan nusantara. Nilai R Square sebesar 0,672 , hal ini berarti $67,2 \%$ kepuasan wisatawan nusantara dapat dijelaskan oleh variabel kualitas pelayanan dan citra merek, sedangkan sisanya sebesar 32,8\% dipengaruhi oleh variabel lain yang tidak diteliti dalam penelitian ini.
\end{abstract}

Keywords: brand image, grab, servicesquality, tourist satisfaction.

\section{PENDAHULUAN}

Bali merupakan Provinsi di Indonesia yang kaya akan keindahan alam, seni dan budaya. Hal tersebut menarik minat wisatawan nusantara hingga mancanegara untuk mengunjungi Pulau Bali. Kedatangan wisatawan sangat bermanfaat bagi kemajuan industri pariwisata Bali. Kemajuan industri pariwisata disuatu daerah dapat dilihat dari seberapa besar daya tarik wisata yang dimiliki oleh suatu Daerah Tujuan Wisata (DTW) dan seberapa besar potensi wisatawan yang datang dari Daerah Asal Wisatawan (DAW).

Berdasarkan data yang dikeluarkan oleh BPS Provinsi Bali, kunjungan wisatawan nusantara ke Bali mengalami peningkatan signifikan dengan jumlah kunjungan wisatawan nusantara sebanyak 9.757.991 wisatawan atau pertumbuhannya sebesar $11,7 \%$ di tahun 2018 dibandingkan dengan tahun 2017 yaitu sebanyak 8.735.633 dengan pertumbuhan sebesar 1,06 wisatawan. Pertumbuhan tersebut memacu industri 
pariwisata Bali agar semakin berbenah diri untuk menunjang kedatangan wisatawan.

Badung menjadi Kabupaten yang menempati posisi nomor satu dengan pendapatan daerah tertinggi di tahun 2018 sebesar 4.555.716.407 (BPS Provinsi Bali, 2019). Pariwisata merupakan salah satu sektor yang berperan besar dalam menyumbang pendapatan daerah Kabupaten Badung, oleh karena itu pemerintah Kabupaten Badung memberikan perhatian bagi pariwisata Badung dengan tujuan memperoleh dampak positif dari industri pariwisata dan menjadikannya sebagai sumber potensial bagi pemasukan pendapatan daerah.

Pariwisata di Kabupaten Badung merupakan sektor yang unggul karena selain sebagai sumber pendapatan daerah juga sebagai pengembangan dan pelestarian budaya dan pembangkit perekonomian masyarakat. Kuta merupakan Kecamatan di Kabupaten Badung yang memiliki beberapa objek wisata yang selalu ramai dikunjungi wisatawan, salah satunya adalah Pantai Kuta.

Dalam mengembangkan suatu destinasi tidak hanya mengandalkan sumber daya alam dan keunikan budaya, namun sarana dan prasarana perlu diperhatikan sebagai komponen pendukung pengembangan destinasi. Transportasi darat merupakan sarana pokok pariwisata yang dapat menunjang kegiatan-kegiatan pariwisata dan mempermudah wisatawan untuk mencapai suatu daerah tujuan wisata. Kebutuhan wisatawan akan sarana transportasi darat yang terus bertambah membuat semakin banyaknya jenis usaha transportasi seperti, bus, taksi lokal, mobil rental dan ojek lokal.

Hadirnya media internet membuat pemenuhan kebutuhan akan banyak hal jauh lebih mudah dan informasi yang dibutuhkan lebih cepat diterima. Berbagai macam produk dan jasa kini ditawarkan melalui internet. Penawaran untuk memudahkan penjualan produk dan jasa secara online disebut $e$ commerce. Hal ini membuat para penyedia jasa transportasi melakukan inovasi dalam menawarkan jasa transportasi dengan menggunakan bantuan internet. Transportasi onlinekini sedang berkembang dan makin diminati di Indonesia. Beberapa aplikasi transportasi online yang ada di Indonesia yaitu Gojek, Grab, Oke Jack, Indo-Jek, Bang Ojek, Tekno, HelooJek, Bojek, Ojek Argo dan Ajo (www.carisinyal.com, 2019), dapat dilihat bahwa jasa transportasi online belakangan ini sedang bertumbuh dan semakin berkembang di Indonesia. Berbagai perusahaan jasa transportasi online bermunculan dan lingkungan yang terus berubah membawa lebih banyak tantangan bagi setiap perusahaan.

Dalam meningkatkan daya saing, perusahaan perlu memberikan pelayanan yang maksimal agar berdampak positif terhadap kepuasan konsumen. Keunggulan suatu jasa adalah tergantung dari keunikan serta kualitas yang diperlihatkan oleh jasa tersebut, apakah sudah sesuai dengan harapan dan keinginan pelanggan (Supranto, 2011). Kualitas pelayanan dapat diketahui dengan cara membandingkan persepsi para konsumen atas pelayanan yang sesungguhnya mereka harapkan dengan pelayanan yang mereka terima. Selain kualitas pelayanan, untuk meningkatkan daya saing dalam menarik konsumen di tengah persaingan jasa transportasi online, citra merek menjadi salah satu variabel yang penting. Sebuah jasa yang memiliki citra yang baik membuat publik cenderung memiliki citra yang baik atau positif termasuk jasanya relatif lebih diterima dan melekat pada benak konsumen.

Grab merupakan sebuah perusahaan teknologi yang berasal dari Singapura yang berekspansi ke Indonesia tahun 2014. Menurut Menteri Pariwisata Arief Yahya (dalam Tirto.id, 2018) aspek transportasi belum mampu mengakomodir kebutuhan wisatawan baik lokal maupun mancanegara. Kendala pada aspek transportasi ini dimanfaatkan Grab Indonesia untuk menciptakan inovasi layanan transportasi antarwisata berbasis aplikasi online, yaitu sewa GrabCar, sebagai bentuk dukungan program Wonderful Indonesia.

Dikutip dari (Detik, 2018) Grab menyebut dirinya "nomor satu di Asia Tenggara", pengajuan klaim tersebut tentunya bukan tanpa alasan dikatakan Grab begitu saja, Grab telah melayani lebih dari 2,5 milyar perjalanan, untuk perharinnya Grab dapat melayani 5,5 juta perjalanan. Hal tersebut juga dapat dilihat pada hasil survei dari Top Brand Index untuk kategori jasa transportasi online di mana pada tahun 2016 pertumbuhan Grab di Indonesia sebesar 14,7\% hingga tahun 2018 Grab mengalami pertumbuhan sebesar $48,0 \%$, namun di tahun 2019 pertumbuhan merek Grab mengalami penurunan yaitu $43,1 \%$. Dapat dilihat bahwa persaingan berebut pasar transportasi berbasis online di Indonesia begitu 
ketat antar jasa transportasi online, kondisi ini mengakibatkan Grab harus berusaha menarik masyarakat dengan meningkatkan pelayanan, kemudahan pemesanan, kenyamanan armada, ketepatan waktu dan lain sebagainya.

Penelitian milik Sinurat, terkait transportasi online Grab (Sinurat dkk, 2018) melakukan pra-survei sederhana untuk 30 pelanggan layanan transportasi online Grab di Kota Medan. Dari hasil survei tersebut, ditemukan tingkat kualitas layanan yang diberikan masih belum cukup dan perusahaan jasa transportasi online Grab harus dapat mengubah kualitas layanannya agar dapat bertahan dan mampu bersaing dengan pesaingnya, terkait citra merek perusahaan transportasi online Grab perlu ditingkatkan. Sebagian besar pelanggan transportasi online Grab puas dengan layanan yang diberikan, tetapi masih ada pelanggan yang tidak puas karena tidak sesuai dengan harapan yang diinginkan. Hal tersebut merupakan tantangan bagi perusahaan transportasi online Grab sehingga dapat menjadi lebih baik di masa depan dan dapat bersaing secara sehat dengan pesaing. Penelitian tersebut menyatakan bahwa citra merek dan kualitas pelayanan masing-masing memiliki pengaruh positif dan signifikan terhadap kepuasan pelanggan yang menggunakan transportasi online Grab di Kota Medan.

Grab telah beroperasi di Bali sebagai jasa transportasi online yang memberikan kemudahan pemesanan tranportasi dengan menggunakan aplikasi. Kehadiran Grab di Bali memberikan reaksi pro dan kontra dari berbagai kalangan.penolakan dan protes keras yang kerap disuarakan oleh pengemudi angkutan jasa konvensional dibeberapa daerah wisata seperti di Seminyak, Canggu, Nusa Dua, dikarenakan beroperasinya tranportasi berbasis online merugikan warga sekitar yang merupakan pengemudi angkutan jasa konvensional mencari nafka diwilayah mereka sendiri.maka pemerintah membuat regulasi taksi online dalam Peraturan Menteri Nomor 26 Tahun 2017 Tentang Penyelenggaraan Angkutan Orang Dengan Kendaraan Bermotor Umum Tidak Dalam Trayek yang di dalamnya mengatur penyelenggaraan angkutan umum dengan aplikasi berbasis teknologi informasi, dengan demikian Grab memiliki legalitas hukum yang jelas.

Dari uraian yang dijabarkan sebelumnya, yaitu penelitian milik Sinurat tentang transportasi online Grab di Kota Medan, penulis ingin mengetahui bagaimana pengaruh kualitas pelayanan dan citra merek terhadap kepuasan wisatawan nusantara di Kuta, Bali. Sehingga penulis tertarik untuk mengankat judul tentang pengaruh kualitas pelayanan dan citra merek terhadap kepuasan wisatawan nusantara menggunakan transportasi online Grab di Kuta, Bali.

\section{METODE PENELITIAN}

Penelitian ini berlokasi di area Jl. Raya Pantai Kuta, di mana pada area tersebut terdapat GrabBooth yaitu booth penjemputan atau meeting point yang terletak di depan Mall Beachwalk. Adapun terdapat tiga variabel yang digunakan dalam penelitian ini, dua variabel independen yaitu kualitas pelayanan (tangibles, reliability, responsiveness, assurance, dan empathy), citra merek (asosiasi merek, dukungan asosiasi merek, kekuatan asosiasi merek dan keunikan asosiasi merek) dan satu variabel dependen yaitu kepuasan wisatawan nusantara.

Teknik pengumpulan data dalam penelitian ini adalah: 1). Observasi, yaitu pengamatan langsung ke lokasi penelitian di area Jl. Raya Pantai Kuta. 2). Wawancara, peneliti akan mewawancarai pihak pengelola perusahaan Grab di Bali, driver Grab dan wisatawan nusantara yang menggunakan transportasi online Grab di Kuta, Bali. 3). Kuesioner, yaitu rangkaian pertanyaan yang dibagikan kepada wisatawan nusantara yang menggunakan jasa transportasi online Grab di Kuta, Bali dan diukur menggunakan skala likert. 4). Dokumentasi, yaitu teknik pengumpulan data berupa foto-foto atau arsiparsip. 5). Studi Kepustakaan, yaitu mengumpulkan data sekunder dari jurnal, website dan buku-buku serta literatur yang sesuai.

Teknik penentuan sampel menggunakan purposive sampling yaitu teknik penentuan sampel dengan pertimbangan tertentu. Pertimbangan yang dimaksud dalam penelitian ini adalah wisatawan nusantara yang pernah menggunakan transportasi online Grab pada saat berkunjung ke Bali. Pada penentuan jumlah sampel, peneliti menggunakan model J. Supranto (Supranto, 2006) yaitu dengan mengalikan 5-10 dengan jumlah indikator sebanyak 30 butir. Maka jumlah responden yang dijadikan sampel yaitu 150 responden 
yang diperoleh dengan mengalikan 5 dengan 30 indikator.

Teknik analisis data yang digunakan adalah statistik deskriptif, uji instrument penelitian yaitu uji validitas dan uji reliabilitas. Setelah instrumen penelitian valid dan reliable maka tahap selanjutnya adalah uji asumsi klasik yaitu uji normalitas, uji multikolinearitas dan uji heteroskedastisitas. Setelah model regresi berdistribusi normal dan bebas dari asumsi klasik maka selanjutnya dilakukan analisis regresi linear berganda. Pada analisis regresi linear berganda juga akan melakukan uji t (parsial) dan uji F (simultan), juga akan dilihat keeratan hubungan antar variabel menggunakan analisis korelasi dan mengukur kemampuan model dalam menerangkan variasi variabel dependen menggunakan uji koefisien determinasi.

\section{HASIL DAN PEMBAHASAN}

Grab merupakan perusahaan layanan pemesanan transportasi berbasis aplikasi yang dapat diunduh di Play Store dan App store. Didirikan pada tahun 2012 oleh Anthony Tan dan Tan Hooi Ling. Anthony Tan adalah warga negara Malaysia dan keluarganya merupakan pebisnis distributor utama mobil Nissan di Malaysia. Ide membuat aplikasi pemesanan taksi memalui smartphone ini dimulai pada saat Anthony menempuh pendidikan di Harvard Business School. Suatu ketika temannya mengeluh tentang buruknya sistem transportasi di Malaysia. Ide dari permasalahan tersebut pun terwujud dengan hadirnya aplikasi MyTeksi yang merupakan tugas sekolahnya hingga berlanjut menjadi bisnis sungguhan yang berganti nama menjadi Grab yang berkantor pusat di Singapura.

Grab telah menyediakan layanan di Singapura, Malaysia, Indonesia, Filipina, Thailand, Vietnam, Myanmar dan Kamboja. Di Indonesia Grab telah hadir di 125 kota mulai dari Banda Aceh hingga Jayapura, Papua. Pada tahun 2015 Grab berekspansi ke Bali yang merupakan destinasi wisata di Indonesia. Kantor Grab Bali beralamat di Jl. Gatot Subroto Barat No. 327 Padang Sambian Kaja, Denpasar Barat. Ekspansi Grab di Bali juga telah diperluas ke Gianyar, Negara dan Singaraja. Sudah 4 tahun Grab beroperasi di Bali, berdasarkan hasil wawancara dengan Staff Marketing Grab, hingga Desember 2018 jumlah pengguna Grab di Bali telah mencapai
$80 \%$. Grab sendiri memiliki 10 fitur layanan jasa pada aplikasinya yaitu GrabTaxi, GrabCar, GrabBike, GrabExpress, GrabFood, Rent, GrabFresh, Rute, Wheels, Bus.

Penelitian ini didasarkan pada 150 responden dengan menggunakan kuesioner yang diberikan pada wisatawan nusantara yang sudah menggunakan transportasi online Grab di Kuta, Bali. Wisatawan nusantara yang menggunakan transportasi online Grab di Kuta didominasi oleh wisatawan nusantara berjenis kelamin perempuan sebanyak 52\%, berdasarkan asal kota didoinasi oleh wisatawan dari Jakarta sebanyak 26,6\%, berdasarkan pekerjaan didominasi oleh pegawai swasta 72,6\%. Responden berdasarkan umur didominasi dengan umur 21-30 sebanyak 54\%, berdasarkan pendidikan terakhir didominasi dengan pendidikan Diploma/ S1/ S2/ S3 sebanyak 66,6\%, berdasarkan penghasilan per bulan didominasi dengan penghasilan $\mathrm{Rp}$ 6.000.000-Rp 8.000 .000 sebanyak $26,6 \%$, berdasarkan pengeluaran selama di Bali didominasi dengan pengeluaran $\mathrm{Rp} \quad 2.000 .000-\mathrm{Rp} \quad 4.000 .000$ sebanyak $36 \%$, berdasarkan frekuensi kunjungan ke Bali didominasi dengan kunjungan 2-5 kali sebanyak 38,6\%, berdasarkan tujuan berkunjung ke Bali didominasi dengan tujuan berlibur sebanyak $100 \%$. Responden berdasarkan sumber infomasi transportasi online Grab didominasi dengan media sosial sebanyak $66,6 \%$, berdasarkan penggunaan transportasi online Grab didominasi dengan penggunaan lebih dari 10 kali sebanyak 50\%.

Berdasarkan kuesioner yang telah diajukan kepada 150 responden, diperoleh berbagai tanggapan terkait variabel kualitas pelayanan, citra merek dan kepuasan wisatawan nusantara terhadap transportasi online Grab di Kuta. Skor rata-rata persepsi wisatawan nusantara terhadap variabel kualitas pelayanan adalah 4,00 dengan kategori setuju. Pada dimensi berwujud (tangibles) pernyataan nomor 1 "Fasilitas transportasi onlineGrabCar (kursi mobil, sefty belt) yang bersih dan lengkap", mendominasi dengannilai rataratasebesar 4,16. Hal ini menunjukan fasilitas transportasi online GrabCar yaitu kursi mobil dan safety belt yang bersih dan lengkap merupakan bagian penting dalam meningkatkan kepuasan wisatawan nusantara. Rata-rata terendah yaitu 3,81 untuk pernyataan nomor 2 "Fasilitas transportasi online 
GrabBike (jok motor, helm) yang bersih dan lengkap".

Pada skor rata-rata persepsi wisatawan nusantara terhadap variabel citra merek adalah 4,00 dengan kategori setuju. Pada dukungan asosiasi merek dengan pernyataan nomor 12 "Grab merupakan transportasi online yang bermanfaat", mendominasi dengan rata-rata 4,38. Hal ini merupakan bukti bahwa wisatawan nusantara telah merasakan manfaat dari penggunaan transportasi online Grab sehingga menghasilkan kepuasan, serta menjadi pendukung citra merek Grab dimata wisatawan nusantara. Rata-rata terendah yaitu 3,54 pada pernyataan nomor 7 "Menggunakan Grab membentuk nilai tambah di mata orang lain".

Pada skor rata-rata persepsi wisatawan nusantara terhadap variabel kepuasan adalah 4,10 dengan kategori setuju. Pada indikator minat pembelian ulang dengan item pernyataan nomor 3 "wisatawan akan menggunakan jasa transposrtasi Grab lagi" yang mendominasi dengan rata-rata 4,20. Hal ini membuktikan Grab berhasil menumbuhkan rasa puas bagi wisatawan nusantara sehingga wisatawan akan menggunakan jasa transportasi Grab kembali. Untuk pernyataan terendah mendapatkan rata-rata 4,02yaitu "Wisatawan puas dengan seluruh pelayanan Grab".

Hasil uji validitas menyatakan bahwa 30 indikator dinyatakan valid. Hasil uji reliabilitas dalam penelitian ini menyatakan bahwa nilai Cronbach's Alpha sebesar 0,968 lebih besar dari 0,6 sehingga instrumen penelitian dapat dikatakan reliable.

Pada uji asumsi klasik terdiri dari tiga pengujian yaitu uji normalitas, uji multikoliniearitas dan uji heteroskedastisitas. Adapun kriteria pada uji normalitas apabila model regresi dikatakan normal atau tidak, jika nilai Sig. >alpha $(0,05)$. Hasil uji normalitas diketahui bahwa nilai Sig. atau Asymp. Sig. (2tailed) bernilai 0,537. Hal tersebut menunjukan bahwa 0,537>0,05, maka dapat disimpulkan bahwa model regresi berdistribusi normal.

Model regresi yang bebas dari gejala multikolinearitas ditandai dengan nilai Toleranceyang lebih besar dari 0,100 dan nilai VIF lebih kecil dari 10,00. Adapun hasil uji multikolinearitas menunjukan bahwa nilai Tolerance 0,335 lebih besar dari 0,100 dan nilai VIF 2,982 lebih kecil dari 10,00. Hal tersebut membuktikan bahwa tidak terjadi gejala mlitikolinearitas.

Selanjutnya uji heteroskedastisitas, sebuah model regresi tidak terjadi heteroskedastisitas jika tidak ada pola yang jelas (bergelombang, melebar, kemudian menyempit) pada gambar scatterplots, serta titik-titik menyebar di atas dan di bawah angka 0 pada sumbu Y. Hasil uji heteroskedastisitas menunjukan bahwa titik-titik tidak membentuk pola yang jelas dan titik-titik menyebar di atas dan di bawah angka 0 pada sumbu $\mathrm{Y}$. Sehingga dapat diasumsikan bahwa tidak ada gejala heteroskedastisitas.

Hasil analisis regresi linear berganda menunjukan bahwa nilai konstanta bernilai positif yaitu sebesar 1,697 dan menunjukan pengaruh positif pada variabel kualitas pelayaan dan citra merek, sehingga dapat dijelaskan bahwa arah hubungan variabel kualitas pelayanan dan citra merek terhadap kepuasan wisatawan nusantara memiliki hubungan yang searah atau positif.

Pada pengujian hipotesis dalam penelitian ini menggunakan uji $\mathrm{t}$ (parsial) dan uji $\mathrm{F}$ (simultan). Tahap selanjutnya pengujian hipotesis menggunakan uji $t$ untuk mengetahui apakah variabel kualitas pelayanan (X1) dan citra merek (X2) secara parsial (sendiri) memiliki pengaruh yang positif dan signifikan atau tidak terhadap variabel kepuasan wisatawan nusantara (Y).

Pada kriteria penerimaan atau penolakan hipotesis terkait pengaruh variabel bebas terhadap variabel terikat adalah sebagai berikut: Jika nilai Sig. $<0,05$ maka variabel kualitas pelayanan dan citra merek secara parsial berpengaruh positif dan signifikan terhadap kepuasan wisatawan nusantara yang menggunakan transportasi online Grab di Kuta, Bali. Jika nilai Sig. > 0,05 maka variabel kualitas pelayanan dan citra merek secara parsial tidak berpengaruh positif dan signifikan terhadap kepuasan wisatawan nusantara yang menggunakan transportasi online Grab di Kuta, Bali.

Hasil dari pengujian uji t menunjukan bahwa nilai Sig. untuk X1 terhadap Y sebesar 0,008 kurang dari 0,05 maka dapat dijelaskan bahwa kualitas pelayanan secara parsial berpengaruh positif dan signifikan terhadap kepuasan wisatawan nusantara yang menggunakan transportasi online Grab di Kuta, Bali. Nilai Sig. untuk X2 terhadap Y sebesar 0,000 kurang dari 0,05 maka dapat 
dijelaskan bahwa citra merek secara parsial berpengaruh positif dan signifikan terhadap kepuasan wisatawan nusantara yang menggunakan transportasi online Grab di Kuta, Bali.

Pada uji F (simultan) dilakukan untuk mengetahui menguji apakah variabel kualitas pelayanan (X1) dan citra merek (X2) secara bersama-sama (simultan) berpengaruh positif dan signifikan terhadap variabel kepuasan wisatawan (Y). Pada kriteria penerimaan atau penolakan hipotesis terkait pengaruh variabel bebas terhadap variabel terikat adalah sebagai berikut:Jika nilai Sig. < 0,05 maka variabel kualitas pelayanan (X1) dan variabel citra merek (X2) secara bersama-sama (simultan) berpengaruh positif dan signifikan terhadap variabel kepuasan wisatawan (Y).Jika nilai Sig. > 0,05 maka variabel kualitas pelayanan (X1) dan variabel citra merek (X2) secara bersama-sama (simultan) tidak berpengaruh positif dan signifikan terhadap kepuasan wisatawan nusantara yang menggunakan transportasi online Grab di Kuta, Bali.

Hasil dari uji $\mathrm{F}$ (simultan) menunjukan bahwa nilai Sig. untuk X1 dan X2 terhadap Y sebesar 0,000 kurang dari 0,05 maka dapat dijelaskan bahwa kualitas pelayanan dan citra merek secara bersama-sama (simultan) berpengaruh positif dan signifikan terhadap kepuasan wisatawan nusantara yang menggunakan transportasi online Grab di Kuta, Bali.

Berdasarkan hasil analisis korelasi diketahui bahwa hubungan antara variabel kualitas pelayanan dan citra merek terhadap kepuasan wisatawan nusantara signifikan karena nilai Sig. (2 tailed) sebesar 0,000 kurang dari 0,05. Arah hubungan juga dapat dilihat dari angka koefisien korelasi kualitas pelayanan dan citra merek yang bernilai positif dan searah yakni 0,734 dan 0,810 . Maka dapat dijelaskan bahwa jika kualitas pelayanan dan citra merek tinggi maka kepuasan wisatawan nusantara juga tinggi.

Nilai koefisien determinasi dapat diukur oleh nilai $R$-Square. Berdasarkan hasil uji koefisien determinasi, dapat diketahui bahwa nilai koefisien determinasi ( $R$ Square) sebesar 0,672. Hal ini berarti $67,2 \%$ kepuasan wisatawan dapat dijelaskan oleh variabel kualitas pelayanan dan citra merek, sedangkan sisanya yaitu $32,8 \%$ kepuasan wisatawan dipengaruhi oleh variabel lainnya yang tidak diteliti dalam penelitian ini.
Dari hasil ini mengungkapkan bahwa kualitas pelayanan berpengaruh positif dan signifikan terhadap kepuasan wisatawan nusantara yang menggunakan transportasi online Grab di Kuta, Bali. Hasil penelitian ini sejalan dengan penelitian dari (Sinurat, dkk 2018) yang menyatakan bahwa kualitas pelayanan memiliki efek positif dan signifikan terhadap kepuasan pelanggan pengguna jasa transportasi online Grab di Medan. Malik (Malik, 2012) dalam penelitiannya juga menyatakan bahwa pada perusahaan layanan, persepsi kualitas layanan memiliki dampak langsung terhadap kepuasan pelanggan bersama dengan kepercayaan pelanggan. Ketika pelanggan mendapat layanan yang lebih banyak dan lebih baik dari apa yang mereka harapkan sebelum pembelian di perusahaan layanan, pelanggan dapat menjadi puas. Ketika pelanggan mendapatkan kualitas pelayanan yang baik dari penyedia layanan, maka kepercayaan dari pelanggan juga terjadi dan pelanggan menganggap bahwa hasil yang lebih bermanfaat akan disediakan oleh perusahaan jasa. Jadi jika kualitas pelayanan semakin ditingkatkan maka kepuasan wisatawan akan terwujud.

Adapun karakteristik wisatawan berdasarkan frekuensi penggunaan transportasi online Grab, didominasi oleh wisatawan nusantara dengan penggunaan lebih dari 10 kali yaitu sebesar 50\%. Hal tersebut dapat diindikasikan bahwa kepuasan wisatawan nusantara pada saat menggunakan Grab mendorong wisatawan untuk menggunakan transportasi online Grab kembali. Pada persepsi wisatawan nusantara terkait variabel kualitas pelayanan transportasi online Grab, didominasi oleh item pernyataan "fasilitas transportasi online GrabCar (kursi mobil, safety belt) yang bersih dan lengkap", dengan skor rata-rata sebesar 4,16 dengan kategori setuju. Hal tersebut ditunjukan oleh driver GrabCar dengan menjaga dan merawat mobil. Kebersihan transportasi dan kelengkapan fasilitas merupakan suatu hal yang dapat memberikan rasa nyaman sehingga dapat menumbuhkan kepuasan bagi wisatawan nusantara. Didapati juga nilai rata-rata terendah yaitu 3,81 dengan kategori setuju untuk item pernyataan "fasilitas transportasi online GrabBike (jok motor, helm) yang bersih dan lengkap".

Adapun hasil wawancara kepada wisatawan nusantara tentang pengaruh kualitas 
pelayanan terhadap kepuasan wisatawan nusantara yang menggunakan tranportasi online Grab di Kuta, Bali yang menyatakan bahwa: "Kualitas pelayanannya perlu ditingkatkan terutama pada waktu penjemputan, kalau bisa plat nomor kendaraan yang digunakan sesuai dengan plat nomor yang ada pada aplikasi" (Bronvil, 28 Agustus 2019). "Pelayanan dari GrabCar sudah baik, mobil bersih, wangi dan nyaman, lagu-lagunya enak didengar" (Lia, 30 Agustus 2019). Berdasarkan hasil wawancara, wisatawan nusantara memberikan respon yang baik terhadap pelayanan yang diberikan oleh transportasi online Grab, beberapa hal diantaranya berupa masukan positif terhadap keamanan dan kenyamanan berkendara. Selain itu, pada penelitian ini diketahui bahwa citra merek berpengaruh positif dan signifikan terhadap kepuasan wisatawan nusantara yang menggunakan transportasi online Grab di Kuta, Bali. Hasil penelitian ini memberikan bukti empiris yang sejalan dengan penelitian sebelumnya milik (Sinurat, 2018), yang menunjukan hasil yang positif dan signifikan antara citra merek dan kepuasan pelanggan pengguna jasa transportasi online Grab di Medan. Penelitian dari Faud (Faud, 2016) menjelaskan bahwa kepuasan pelanggan dipengaruhi oleh citra merek. Citra yang melekat pada sebuah merek dapat memberikan kepuasan pada pelanggan melalui psikolog pelanggan. Pelangaan akan merasa puas ketika citra merek produk yang digunakan tergolong baik dan terkenal sehingga mudah untuk diingat.

Pada karakteristik wisatawan berdasarkan sumber informasi tentang transportasi online Grab, didominasi oleh media sosial sebanyak 66,6\%. Hal ini membuktikan bahwa promosi yang dilakukan Grab melalui media sosial berhasil memperkenalkan citra merek Grab kepada wisatawan nusantara. Selain itu dilihat dari persepsi wisatawan nusantara terkait variabel citra merek transportasi online Grab, didominasi oleh item pernyataan "Grab merupakan transportasi online yang bermanfaat" dengan skor rata-rata 4,38 dengan kategori sangat setuju. Bermanfaat karena wisatawan dengan mudah dapat memesan Grab menggunakan smartphone yang mana aplikasi Grab dapat didownload melalui Play Store atau App Store, sehingga wisatawan tidak perlu menyewa kendaraan selama berlibur di Bali, wisatawan juga dapat mengetahui estimasi biaya perjalanan secara transparan, jarak tempuh perjalanan hingga metode pembayaran digital karena semua hal tersebut dicantumkan pada aplikasi dan dibuat dengan terperinci, serta armada Grab mudah dicari karena selalu tersedia selama 24 jam. Didapati juga nilai rata-rata terendah yaitu 3,54 dengan kategori setuju untuk item pernyataan "menggunakan Grab membentuk nilai tambah dimata orang lain". Hal tersebut mengindikasikan bahwa pada saat menggunakan transportasi online Grab, wisatawan nusantara telah merasakan kepuasan dalam mengekspresi diri pada lingkungan sosialnya.

Adapun hasil wawancara yang dilakukan kepada wisatawan nusantara pengguna tranportasi online Grab di Kuta, Bali yaitu:"Pakai Grab itu sangat bermanfaat, pengguna bisa tiba ditujuan dengan cepat" (Reza, 30 Agustus 2019). "Aplikasi pemesanan Grab sangat mudah digunakan dan tidak membingungkan," (Lia, 30 Agustus 2019). Berdasarkan hasil wawancara terlihat bahwa Grab memiliki reputasi yang baik, hal ini membuat ingatan wisatawan semakin kuat terhadap transportasi online Grab, sehingga dapat diindikasikan bahwa Grab telah menumbuhkan citra merek bagi wisatawan. Pada pengaruh kualitas pelayanan dan citra merek terhadap kepuasan wisatawan didapati bahwa kualitas pelayanan dan citra merek berpengaruh positif dan signifikan terhadap kepuasan wisatawan nusantara yang menggunakan transportasi online $\mathrm{Grab} \mathrm{di}$ Kuta, Bali. Hasil penelitian ini sejalan dengan penelitian milik (Puriani, 2017) yang menyatakan citra merek dan kualitas pelayanan berpengaruh positif dan signifikan terhadap kepuasan wisatawan dalam memilih taksi Blue Bird di Bali. Ada pula nilai dari koefisien determinasi sebesar 0,672. Hal ini menjelaskan bahwa $67,2 \%$ kepuasan wisatawan nusantara yang menggunakan transportasi online Grab di Kuta, Bali dipengaruhi oleh kualitas pelayanan dan citra merek, sementara sisanya yaitu $32,8 \%$ dipengaruhi oleh variabel lain yang tidak diteliti dalam penelitian ini. Variabel-variabel lainnya seperti price/ harga yaitu penghematan biaya perjalanan, persaingan harga dan variabel kepercayaan yaitu kepercayaan pada aplikasi Grab. Dari hasil penelitian ini dapat dijelaskan bahwa kualitas pelayanan dan citra 
merek merupakan hal penting dalam menciptakan kepuasan wisatawan nusantara. Terciptanya kepuasan membuat wisatawan akan memberikan perhatian terhadap produk/ jasa baru dari Grab yang mungkin bermanfaat bagi wisatawan, apabila nilai kualitas pelayanan dan citra merek yang diberikan kepada wisatawan semakin tinggi maka semakin tinggi pula kepuasan wisatawan.

\section{SIMPULAN DAN SARAN Simpulan}

Berdasarkan hal tersebut maka diperoleh hasil bahwa kualitas pelayanan secara parsial berpengaruh positif dan signifikan terhadap kepuasan wisatawan nusantara yang menggunakan transportasi online Grab di Kuta, Bali dan ditemukan bahwa pada variabel kualitas pelayanan, dimensi variabel yang mendominasi adalah dimensi berwujud (tangibles).

Berdasarkan hal tersebut maka diperoleh hasil bahwa citra merek secara parsial berpengaruh positif dan signifikan terhadap kepuasan wisatawan nusantarayang menggunakan transportasi online Grab di Kuta, Bali dan ditemukan bahwa pada variabel citra merek, dimensi variabel yang mendominasi adalah dimensi dukungan asosiasi merek.

Berdasarkan hal tersebut maka diperoleh hasil bahwa kualitas pelayanan dan citra merek secara simultan berpengaruh positif dan signifikan terhadap kepuasan wisatawan nusantara yang menggunakan transportasi online Grab di Kuta, Bali.

\section{Saran}

Apabila pengemudi menggunakan kendaraan dengan plat nomor yang berbeda dengan plat nomor yang tertera pada aplikasi diharapkan untuk menginformasikan kepada wisatawan. Terkait keamanan berkendara, service kendaraan perlu dilakukan untuk memastikan kendaraan dalam keadaan baik, helm yang digunakan oleh penumpang GrabBike selalu dijaga kebersihannya dan dalam keadaan baik agar wisatawan merasa nyaman menggunakannya dan Grab perlu meningkatkan kesan positif terhadap wisatawan nusantara sebagai transportasi online sehingga membentuk nilai tambah dimata wisatawan.
Saran akademis bagi penelitian selanjutnya, dalam penelitian ini ditemukan bahwa 32,8\% kepuasan wisatawan nusantara dipengaruhi oleh variabel lain yang tidak diteliti dalam penelitian ini, untuk itu peneliti menyarankan perlu adanya penelitian pada variabel lainnya seperti harga, karena harga merupakan suatu variabel yang diperhatikan wisatawan terkait penghematan biaya perjalanan dan kepercayaan pada aplikasi Grab. Wisatawan nusantara juga telah menggunakan transportasi online Grab lebih dari 10 kali, untuk itu peneliti menyarankan perlu dilakukannya penelitian terkait variabel loyalitas. Terkait responden yang digunakan dalam penelitian selanjutnya diharapkan menggunakan wisatawan mancanegara sehingga dapat dilihat jika terdapat perbedaan penilaian antara wisatawan nusantara dan mancanegara. 


\section{Kepustakaan}

Faud, Muhammad. 2016. Pengaruh Persepsi Harga, Kualitas Layanan dan Citra Merek terhadap Kepuasan Pelanggan Pada Pengguna Bus Trans Jogja di Yogyakarta. Yogyakarta: Skripsi Program Studi Manajemen Fakultas Ekonomi Universitas Negeri Yogyakarta.

Malik, Prof. Dr. Muhammad Ehsan, Muhammad Mudasar Ghafoor dan Hafiz Khashif Iqbal. 2012. Impact of Brand Imagem, Service Quality and Price on Customer Satisfaction in Pakistan Telecommunication Sector. Pakistan: International Journal of Business and Social Science.

Puriani, Dewa Ayu Putu Mega. 2017. Pengaruh Brand Image dan Kualitas Pelayanan terhadap Kepuasan Wisatawan Dalam Memilih Taksi Blue Bird di Bali. Denpasar: Jurnal IPTA Vol. 5 No.1.

Sangadji, Etta Mamang \& Sophia. 2013. Perilaku Konsumen Pendekatan PraktisDisertai: Himpunan Jurnal Penelitian. Yogyakarta: Andi.

Sinurat, Japuti, Fauzi Amrin, Arlina Lubis \& Agus Ismawan. 2018. The Influence of Brand Image and Service Quality on Customer Satisfaction and It's Effect on Customer Loyalty in Using Grab Online Transportation in Medan. Medan: International Organization of Scientific Research Journal of Businessand Management (IOSR-JBM).

Supranto, J. 2011. Pengukuran Tingkat Kepuasan Pelanggan. Jakarta: PT. Rineka Cipta.

Badan Pusat Statistik, 2018. Badan Pusat Statistik Provinsi Bali. Diakses pada tanggal 9 April 2019 dari https://bali.bps.go.id,

Carisinyal.2019. 10 Aplikasi Ojek Online Terbaik dan Terpopuler di Indonesia. Diakses pada tanggal 9 September 2019 dari https://www.carisinyal.com.
Detik. 2018. Grab: Kami Nomor Satu di Asia Tenggara. Diakses pada tanggal 2 Desember 2018 dari https://m.detik.com/inet/bussines/d4319938/grab-kami-nomor-satu-di-asiatenggara.

Tirto.id. 2018. Mentri Pariwisata: Nilai Transportasi Kita Masih Rendah. Diakses pada tanggal 8 November 2018 dari https://tirto.id/menteri-pariwisatanilai-transportasi-kita-masih-rendahc8FS.

Top Brand Award. 2019. Top Brand Index Kategori: Jasa Transportasi Online. Diakses pada tanggal 3 September 2019. https://www.topbrandaward.com/en/2018/07/jasatransportasi-online-2018. 